\title{
THE STOGKHOLDER'S COMMON LAW RIGHT TO NOTICE OF BUSINESS TO BE TRANSACTED AT MEETINGS
}

THE EXTENSIVE DISCUSSION ${ }^{1}$ devoted during the past fif"proxy-rules" promulgated under Section I4(a) of the Securities Exchange Act of $1934^{3}$ has all but obscured the rather meager consideration $^{4}$ of corporate proxy law beyond the reach of this federal regulation. ${ }^{5}$

This latter dearth of recent scholarly consideration, however, by no means reflects the comparative importance of the common law rules which, in fact, govern the majority of American corporations in this respect. Rather, it would seem possibly to indicate a need for their current re-examination, redefinition, and re-evaluation. To this end, attention will here be directed to a study of a particularly incoherent segment

${ }^{2}$ E.g., Loss, Securities Regulation 52I-6I (195I); Bayne, Around \& Beyond the SEC-The Disenfranchised Stockholder, 26 IND. L.J. 207 (195I); Caplin, Proxies, Anntal Meetings and Corporate Democracy: The Lawyer's Role, 37 VA. L. REv. 653 (1951); Emerson and Latcham, SEC Proxy Regulation: Steps Toward More Effective Stockholder Participation, 59 YALE L.J. 635 (1950); Emerson and Latcham, Further Insight into More Effective Stockholder Participation: the Sparks-Worthington Proxy Contest, 60 YAlE L.J. 429 (195I); Friedman, SEC Regulation of Corporate Proxies, 63 HARv. L. REv. 796 (1950); Bernstein \& Fischer, The Regulation of the Solicitation of Proxies: Some Reflections on Corporate Democracy, 7 U. CHI. L. Rev. 226 (1940); Dean, Non-Compliance with Proxy Regulations: Effect on Ability of the Corporation to Hold a Valid Meeting, 24 CoRnell L. Q. 483 (1939); Emerson and Latcham, The SEC Proxy Proposal Rule: The Corporate Gadfly, I9 U. CHI. L. REv. 807 (1952); Notes, 57 Yale L.J. 874 (1948); 33 ILL. L. Rev. 914 (1939); 53 HaRv. L. Rev. I165 (1940); 21 Temple L.Q. 406 (1948).

${ }^{3}$ The "proxy rules" most pertinent to the following discussion are: Rule $\mathrm{X}-14 \mathrm{~A}-3$ and its adjunct Schedule $x_{4} A$, which prescribe in detail the information to be included in the proxy statements; Rule $\mathrm{X}-\mathrm{I}_{4} \mathrm{~A}-5$, which outlines how the information shall be presented; Rule $\mathrm{X}-\mathrm{I}_{4} \mathrm{~A}-9$, which prohibits false or misleading statements; Rule $\mathrm{X}-1_{4} \mathrm{~A}-4$, which requires that the corporation provide a means by which the stockholders can specify their vote on each matter to be acted upon; Rule X-14A-7, specifying the information which must be mailed to a stockholder at his request; and Rule X-r 4 A-8, which requires the publication of stockholders' proposals by the corporation.

${ }_{4}^{3} 8$ STAT. 88 I (1934), I5 U.S.C. $\$ \S 78$ a et seq. (1946).

48I Sor. J. 875 (1937); Note, 5I A.L.R. 94I (1927).

- These proxy rules govern solicitations only by companies regulated by the Securities Exchange Act, which comprise corporations with securities listed on the national securities exchanges, and by companies subject to the Public Utility Holding Company Act of 1935 under $\$ 12,49$ STAT. 823 (1935), 15 U.S.C. $\$ 79 \mathrm{k}(\mathrm{g})(1940)$ and the Investment Company Act of r 940 under $\S 20(a), 54$ STAT. 822, I5 U.S.C. $\$$ Soa-2o(a) (1940). 
of these common law rules-those specifying the notice that must be given to stockholders in order to validate proceedings at a subsequent stockholders' meeting-with a view toward rearticulating their purpose and the proper scope of their operation.

\section{The Present Confusion in the Law}

The generalized statement of the law in this area is well recognized: $:^{8}$ corporate affairs of an unusual or extraordinary character may not properly be brought before a meeting without prior notice to the stockholders. ${ }^{7}$ Charter ${ }^{8}$ or by-law ${ }^{9}$ amendments and mergers ${ }^{10}$ would obviously be within the class of business which must thus be specifically noted. Regular corporate elections ${ }^{11}$ and approval of the reports of

${ }^{5} 5$ Fletcher Cyc. Corp. $\$ \S 2008,2009$ (Perm. ed. 1952); Stevens, Corporatrons $\S$ xig, at 538-39 (2d ed. 1949); 3 Cook, Corporations $§$ 595 (8th ed. 1923); Ballentine, Corporations $\S$ I7 T (revised ed. 1946); ANGell \& AMEs, Corporations $\S \S 488-89$ ( 1 rth ed. 1882 ); r Beach, Private Corporations $\S 279$ (1891); I Morawetz, Private Corporations $\$ 482$ (2d ed. 1886 ); 2 Thompson, CorporaTIONS $\$ \$ 906,926$ (3d ed. 3927 ).

${ }^{7}$ Atlantic Mutual Fire Ins. Co. v. Sanders, 36 N.H. 252 ( 8858 ); Warner v. Mower, II Vt. 385 (1839); Des Moines Life \& Annuity Co. v. Midland Ins. Co., 6 F.2d 228 (D. Minn. I925); Bagley v. Reno Oil Co., 201 Pa. 78, 50 Atl. 760, 56 L.R.A. I 84 ( I902). Notices of special meetings must state the object thereof, and no business other than that stated may be considered. Noremac v. Centre Hill Court, I64 Va. I5I, I78 S.E. 877 (I935); Cooper v. Central Alloy Steel Corp., 43 Ohio App. 455, I83 N.E. 439 (193 I); Synnott v. Cumberland Bldg. \& Loan Ass'n, II7 Fed. 379 (6th Cir. I902); Citrus Growers' Development Ass'n v. Salt River V. W. Users' Ass'n, 34 Ariz. I05, 268 Pac. 773 (I928); Dolbear v. Wilkinson, 172 Cal. 366, is6 Pac. 488 ( 5916 ); American Tube Works v. Boston Mach. Co., 193 Mass. 5, 29 N.E. 63 (1885); People's Mutual Ins. Co. v. Westcott, 14 Gray 440 (Mass. 1860); Tuttle v. Michigan Air Line R.R., 35 Mich. 247 ( 1877 ).

${ }^{8}$ Johnson v. Tribune-Herald Co., 155 Ga. 204, I 6 S.E. 810 (1923).

- Bushway Ice Cream Co. v Fred H. Bean Co., 284 Mass. 239, 187 N.E. 537 (1933); Klein v. Scranton Life Ins. Co., 139 Pa. Super. 369, I1 A.2d 770 (1940); Rogers v. Hill, 6o F.2d 109 (2d Cir. 1932); Synnott v. Cumberland Bldg. \& Loan Ass'n, $1 \times 7$ Fed. 379 (6th Cir. I902) ; Jones v. Concord \& M. R.R., 67 N.H. 119, 38 Atl. I20 (1892); Mutual Fire Ins. Co. of Montgomery County v. Farquhar, 86 Md. 668, 39 Atl. 527 (1898); Bagley v. Reno Oil Co., 201 Pa. 78, 50 Atl. 760, 56 L.R.A. I84 (1902); In re Fleetwood Bank, 283 N.Y. 157, 27 N.E.2d 974, reversing, 258 App.Div. 1057, 17 N.Y.S.2d 691 (1940); Gow v. Consolidated Coppermines Corp., I 9 Del. Ch. I72, I65 Atl. 136 (1933).

${ }^{10}$ Jones v. Commonwealth Edison Co., 297 Ill.App. 513 , 88 N.E.2d $11_{3}$ (1938); Cooper v. Central Alloy Steel Corp., 43 Ohio App. 455, I83 N.E. 439 (193I).

${ }_{11}$ "It is . $\therefore$ almost an invariable statutory requirement that a regular meeting for the election of directors be held annually." STEVENS, CoRporations \$ I 19, at 538 (2d ed. 1949). Likewise corporate charters or by-laws usually provide for the election of directors at the annual meetings. In Sampson v. Bowdoinham Steam Mill Corp., 36 Me. 78 (1853), where the by-laws provided both that the directors should be elected annually and that specific notice of all business to be conducted at annual meetings 
officers $^{12}$ would, on the other hand, fall within the normal course of activities. Intermediate examples present questions of degree, and dividing lines might be expected to have crystallized as factual situations arose in a case-to-case evolutionary process. The course of judicial decisions in this penumbral area, however, has not paralleled the ordinaryextraordinary business dichotomy - at least as these terms are commonly understood. Confusion has arisen from the fact that cases which purportedly have turned on this distinction have involved attacks not only by stockholders actually claiming disenfranchisement by inadequate notice, but also by parties in such grossly disparate situations as the following: creditors seeking priority over other creditors; ${ }^{13}$ stockholders suing promoters for a breach of fiduciary duty $;^{14}$ a dominant director seeking to avoid an unfavorable contract with another corporation; ${ }^{15}$ fully informed owners of a close corporation fighting for control; ${ }^{16}$ a reneging stockholder of an insolvent corporation seeking to avoid liability for subscription price; ${ }^{17}$ and, conversely, a corporation resisting payment of further dividends on stock originally issued at an inadequately noticed meeting. ${ }^{18}$

Attempts to accommodate these multifarious interests within the narrow limits of notice requirement rules have resulted in the generation of numerous inconsistencies in doctrinal pronouncement and in application. The invocation of classic agency concepts ${ }^{19}$ and of such doc-

should be given to stockholders, the court held that the first provision was sufficient notice of the election of directors and that the second provision referred to all other business. Such elections held at special shareholders' meetings, however, are irregular and notice must be given that this action is contemplated. Dolbear v. Wilkinson, 172 Cal. 366, I56 Pac. 488 (I916); People's Mutual Life Ins. Co. v. Westcott, I4 Gray 440 (Mass. I860) ; Dunster v. Bernards Land \& Sand Co., 74 N.J.L. I32, 65 Atl. I23 (1906). Contra: Lawrence v. I. N. Parlier Estate Co., I 5 Cal.2d 220, 100 P.2d 765 (I940).

${ }^{12}$ Starrett Corp, v. Fifth Ave. \& Twenty-Ninth St. Corp., I F. Supp. 868 (S.D. N.Y. I932).

${ }^{13}$ Evans v. Boston Heating Co., 157 Mass. 37, 3 I N.E. 698 (1892); Beecher v. Marquette \& Pacific Rolling Mill Co., 45 Mich. 103, 7 N.W. 695 (188I).

14 Tompkins v. Sperry, Jones \& Co., 96 Md. 560, 54 Atl. 254 (I903).

${ }^{15}$ Des Moines Life \& Annuity Co. v. Midland Ins. Co., 6 F.2d 228 (D. Minn. I925).

${ }^{10}$ People v. Mathiesson, 269 Ill. 499, 109 N.E. 1056 (I9I 5) ; Dunster v. Bernards Land \& Sand Co., 74 N.J.L. 132, 65 Atl. 123 (1906).

${ }^{17}$ Columbia Nat'l Bank v. Mathews, 85 Fed. 934 (9th Cir. 1898); American Tube Works v. Boston Mach. Co., I39 Mass. 5, 29 N.E. 63 (1885).

${ }^{18}$ Richardson v. Vermont \& Massachusetts R.R., 44 Vt. 613 (1872).

${ }^{10}$ Gray v. Aspironal Laboratories, 24 F.2d 97 (5th Cir. I928); Columbia Nat'1 Bank v. Mathews, 85 Fed. 934 (9th Cir. I898). The relationship of shareholder to proxy-holder is most frequently categorized in terms of principal and agent. Bache $v$. Central Leather Co., 78 N.J. Eq. 484, 8 I Atl. 57 I (I9II); Warren v. Pim, 66 
trines as waiver of notice by the duly appointed proxy, ${ }^{20}$ estoppel by participation $^{21}$ or receipt of benefits, ${ }^{22}$ and laches by the stockholder, ${ }^{23}$ has largely cancelled the force of the allegedly general rules requiring notice by the development of a complete repertory of contradictory alternatives. This wide choice of rationales has, in several instances, enabled courts to achieve equitable results in cases where the claim of inadequate notice was interposed in attempts to secure an unconscionable advantage in matters not directly affected by such lack of notice. ${ }^{24}$ Unfortunately, however, other courts have lost sight of the basic reasons for requiring notice and have been driven to manifestly inequitable

N.J. Eq. 353, 59 Atl. 773 (1904). See Stevens, Corporations $§ 118$ (2d ed. 1949). Accordingly, proxy-holders have been classified as "general agents" and "special agents" in order to define more definitely their powers to bind the shareholder. Emerson \& Latcham, SEC Proxy Regulation: Steps Toward More Effective Stockholder Participation, 59 YAlE L.J. 635, 636 n. 7 (1950). See also 33 ILL. L. REv. 914, 916 (1939). ${ }_{20}$ Synnott v. Cumberland BIdg. \& Loan Ass'n, ${ }_{17}$ Fed. 379 (6th Cir. 1902); M'Clean v. Bradley, 282 Fed. 101 I (N.D. Ohio 1922); Gray v. Aspironal Laboratories, 24 F.2d 97 (5th Cir. 1928); Mackenzie v. Taggart, ror Colo. 357, 73 P.2d 978 (1937); Beggs v. Myton Canal \& Irrigation Co., 54 Utah 120, 179 Pac. 984 (I919); Foote v. Greilick, I 66 Mich. 636, I32 N.W. 473 (IgII); Columbin Nat'1 Bank v. Mathews, 85 Fed. 934 (9th Cir. 1898); Seaman v. Ironwood Amusement Corp., 283 Mich. 220, 278 N.W. 51 (1938); Tompkins v. Sperry, Jones \& Co., $96 \mathrm{Md}$. 560,54 Atl. 254 (1903).

${ }^{21}$ Weinburgh v. Union St. Ry. Advertising Co., 55 N.J. Eq. 640,37 Atl. 1026 (1897); Smith v. Stone, 21 Wyo. 62, I28 Pac. 6I2 (1912); Gewasi v. Societa Guiseppi Garibaldi, 96 Conn. 50, 1 I2 Atl. 693 (192I). Contra: Klein v. Scranton Life Ins. Co., 139 Pa.Super. 369 , in A.2d 770 (1940).

${ }_{22}$ Comm'r of Banks v. Tremont Trust Co., 259 Mass. 162, 156 N.E. 7 (1927). Contra: American Tube Works v. Boston Mach. Co., 139 Mass. 5, 29 N.E. 63 (1885).

${ }^{23}$ In Synnott v. Cumberland BIdg. \& Loan Ass'n, 117 Fed. 379, 385 (6th Cir. 1902) the court said that "nothing but the most active diligence in repudinting what was there done in [a stockholder's] name and by her apparent consent can avoid the consequences of her agent's action [i.e., the vote of her proxy-holder]." In that case the stockholder had waited one year before attacking a by-law amendment approved at an inadeguately noticed special meeting. In Gottlieb v. McKee, 107 A.2d 240 (Del. Ch. 1954), however, the court refused to sustain the defendant's contention that the plaintiff should be barred by laches for "failiug to assert the illegality of the transaction for a period of over five years, notwithstanding her knowledge of the alleged acts of wrongdoing." Brief for Defendant-Appellant, p. I. Consider also M'Clean v. Bradley, 282 Fed. IоI (N.D. Ohio I922), where a forner stockholder was attacking the ratification of a mortgage after an interval of 12 years and the court chose to deny relief on the ground that the plaintiff's proxy-holder had waived adequate notice by voting at the meeting-surely a theory that does greater violence to the rules requiring notice than would a laches rationalization.

${ }^{24}$ Mackenzie v. Taggart, xor Colo. 357, 73 P.2d 978 (I937); Columbia Nat'1 Bank v. Mathews, 85 Fed. 934 (9th Cir. I 898 ); Foote v. Greilick, 166 Mich. 636, 132 N.W. 473 (1911); M'Clean v. Bradley, 282 Fed. ror1 (N.D. Ohio 1922). 
conclusions by the uncritical recognition of one particular line of reasoning to the exclusion of all others. ${ }^{25}$

\section{Reappraisal of Basic Concepts and a New Ciassification OF CASES}

The rules requiring advance notice of any extraordinary business to be conducted at a meeting were evidently fostered by a felt necessity for the protection of stockholders' interests. The fundamental premise underlying this protection is that the right to be adequately informed is a necessary adjunct to the exercise of the ultimate control vested in the stockholders. This right, of course, is qualified to the extent that it impinges upon other rights recognized by the law in the business community. Specifically, these other rights may be categorized into two groups. First, non-dissenting stockholders in the enterprise have an interest in having its business conducted smoothly and without the overbearing demands or regressive litigation of a contentious few. Second, third parties have a right to expect that their dealings with the corporation will have a finality not to be impaired by defects of internal management.

The necessity for defining as precisely as possible the dividing lines between these conflicting interest demands a test by which to determine when these notice rules may validly be invoked. Since the conclusion that a stockholder may or may not claim the protection of the rules is usually reached, at least ostensibly, by a determination of whether or not the business conducted was extraordinary, the proper approach would appear to be a phrasing of criteria by which the extraordinary content of business arising at a stockholders' meeting may be gauged. In this connection, the mere characterization of business as "important" is not instructive, for the importance of a matter varies with the business aspects to which the term has reference. ${ }^{26} \mathrm{~A}$ contract, for example, may be "important" because of the monetary consideration involved; or because of the long-term nature of its commitments; or then again because of the extent to which it will necessitate or conduce a change in future corporate policies. ${ }^{27}$

Some commentators have asserted that the basis for requiring notice

${ }^{28}$ American Tube Works v. Boston Mach. Co., 139 Mass. 5, 29 N.E. 63 (1885); Gray v. Aspironal Laboratories, 24 F.2d 97 (5th Cir. 1928); Baillie v. Oriental Tel. \& Elec. Co., [1915] x Ch. 503 .

${ }^{20}$ The corporation laws of most states require a vote of the shareholders on certain specified transactions, e.g., employee stock option plans. It would seem that any matter so singled out by the legislature would be "important" business in all respects, and so would demand specific notice unless otherwise provided by the statute. See CaI. Corp. CODE ANN. § 2201 (Deering I953).

${ }^{27}$ See Chicago, R.I. \& P. Ry. v. Union Pac. Ry., 47 Fed. 15 (C.C. Neb. 1891). 
of only unusual business is the assumption that the stockholders expect action only on business of an ordinary nature. ${ }^{28}$ It would follow that the decisive characteristic of an extraordinary matter should be the extent to which surrounding circumstances give rise to an expectation that it will be considered at a meeting. ${ }^{20}$ The language in several cases seems to be in accord with this analysis, ${ }^{30}$ but the difficulties arising

${ }^{28}$ Angeli \& Ames, Corporations $\$ 488$ ( 1 ith ed. 1882 ); I Beach, Private Corporations $\$ 279$ (189x); I Morawetz, Private Corporations $\$ 479$ (2d ed. 1886 ). It will be noted that all of these works are now rather outdated. This might suggest that increasing economic complexity has forced corporation law away from the original proposition that stockholders should exercise their franchise by consulting and deliberating together, and that pure democracy in corporate government has given way to a representative form, with stockholders appointing proxy-holders to vote for them. Acceptance of this proposition would compel the conclusion that the function of notice of meetings is to enable the stockholders to choose their representative proxy-holders intelligently. See note 29 infra. This thesis has considerable appeal when applied to large public issue corporations. In the case of a close corporation, however, it is not impracticable for all stockholders to attend meetings and have the benefit of each other's experience and advice. This suggests the further thought that perhaps one set of rules should apply to large corporations (representative government) and a wholly different set to small corporations (pure democracy).

${ }^{29} \mathrm{~A}$ reasonable-expectancy test such as this presupposes that the purpose to be accomplished by giving notice to stockholders is only to warn them that a certain general subject matter will be considered, not to furnish them with information upon which their judgment may operate and from which they may draw a conclusion as to the wisdom of the proposed action. The divergence of opinion (more often subconscious than not) on this particular point finds expression in the wide conflict as to what degree of specificity in a notice of meeting will suffice and to what extent it is incumbent upon the stockholder to resort to outside sources for further enlightenment. Of course, a great varicty of considerations, unique in every case, enters into a court's decision as to whether a notice of meeting should contain a speeification of details; but it is believed that the following two groups of cases reflect fundamentally different evaluations of what ends are to be served by such notice:

Details required: Klein v. Scranton Life Ins. Co., 139 Pa. Super. 369, II A.2d 770 (I940); United Gold \& Platinum Mines Co. v. Smith, 44 Misc. 567, 90 N.Y. Supp. 199 (Sup. Ct. 1904); Jones v. Commonwealth Edison Co., 297 Ill. App. 5 I 3 , 18 N.E.2d I13 (1938); In re Bridport Old Brewery Co., L.R. 2 Ch. I91 (1867); Baillie v. Oriental Tel. \& Elec. Co., [1915] x Ch. 503; Pacific Coast Coal Mines Ltd. v. Arbuthnot, [1917] A. C. 607. See note 62 infra.

Details not required: Rogers v. Hill, 60 F.2d rog (2d Cir. 1932); Koplar v. Warner Bros. Pictures, Ig F. Supp. 173 (D. Del. 1937); Cooper v. Central Alloy Steel Corp. 43 Ohio App. 455, 183 N.E. 439 (1931) ; Jones v. Concord \& M. R.R., 67 N.H. 234 30 Atl. 614 (1892); Evans v. Boston Heating Co., 157 Mass. 37,31 N.E. 698 (1892).

${ }^{30}$ "By experience and observation we know that at these regular annual meetings. only the general, routine business is transacted." Bagley v. Reno Oil Co., 201 Pa. 78, 81,50 Atl. 760, 761 (1902). "[No] reasonable construction of this notice would give any intimation to the stockholder that such a resolution . . . would come before the meeting." United Gold \& Platinum Mines Co. v. Smith, 44 Misc. 567, 572, 90 N.Y. Supp. 199, 202 (Sup. Ct. I904). "In the absence of such notice, a stockholder would 
from its application ${ }^{31}$ and the number of cases not readily reconcilable with its precepts ${ }^{32}$ suggest its rejection.

Further analysis of the cases themselves suggests instead the following possible test. The extraordinary content of corporate business for notice requirement purposes is determined by the degree to which that business departs from the normal function of furthering the basic ends of the corporation and develops one or more of three tendencies: (I) to make what are commonly designated as "fundamental changes" in the corporate existence; ${ }^{33}$ (2) to vary the governing rules of the corporation ${ }^{34}$ and ( 3 ) to advance exclusively the interests of manage-

have no reason to believe that this important business would be transacted. . . ." Dolbear v. Wilkinson, $I_{72}$ Cal. 366,369 , I56 Pac. 488, 490 (I916). See also Logie v. Mother Lode Copper Mines Co. of Alaska, I 06 Wash. 208, I79 Pac. 835 (1919); Lawrence v. I. N. Parlier Estate Co., I5 Cal.2d 220, roo P.zd 765 (x940); Dunster


Annuity Co. v. Midland Ins. Co., 6 F.2d 228 (D. Minn. 1925).

${ }^{31}$ Consider, e.g., whether a court in any case would conclude that the financial difficulties of the corporation should give rise to the expectation that dissolution would be considered at the annual meeting. The verbal integrity of the reasonable expectancy formula might be preserved in such a case by saying that the stockholders would not expect anything that drastic; but such circuity of reasoning would obviously impair the value of the formula for determining the "importance" of business in borderline cases.

${ }^{32}$ Those cases proceeding from the premise that the notice of business to be conducted should enable the stockholder to decide how he would vote (note 29 supra) are basically repugnant to an expectancy analysis. See also Gottlieb v. McKee, xo7 A.2d 240 (Del. Ch. 1954), where the court held that although the notice of meeting recounted the full details of an alleged appropriation of a corporate opportunity by the directors, the stockholder was not expected to anticipate that another stockholder would move to ratify the directors' action at the annual meeting.

${ }^{33}$ McKee v. Home Savings \& Trust Co., 122 Iowa 73x, 98 N.W. 609 (I904) (dissolution); Smith v. Stone, 2 I Wyo. 62, 128 Pac. 612 (1912) (sale of assets); Johnson v. Tribune-Herald Co., 155 Ga. 204, I 66 S.E. 810 (1923) (merger); Starrett Corp. v. Fifth Ave. \& Twenty-Ninth St. Corp., I F. Supp. 868 (S.D.N.Y. I932) (sale of assets); St. Mary's Benevolent Ass'n v. Lynch, 64 N.H. 213, 9 Atl. 98 (r887) (dissolution); Stockholders of Shelby R.R. v. Louisville, C. \& L. R.R., I2 Bush 62 (Ky. 1876) (sale of assets) ; Beggs v. Myton Canal \& Irrigation Co., 54 Utah 1 20, 179 Pac. 984 (1919) (sale of assets); Germer v. Triple-State Natural Gas \& Oil Co., 6o W.Va. 143,54 S.E. 509 (Ig06) (sale of assets); Elster v. American Airlines, roo A.2d $2 \times 9$ (Del. Ch. I953) (gift of corporate property); In re Bridport Old Brewery Co., L.R. I Ch. I9I ( 1867 ) (dissolution); Tuttle v. Michigan Air Line R.R., 35 Mich. 247 ( 1877$)$ (consolidation).

${ }^{34}$ Klein v. Scranton Life Ins. Co., I39 Pa. Super. 369, II A.2d 770 (I940); Jones v. Concord \& M. R.R., 67 N.H. I19, 38 Atl. I2o (1892); Bushway Ice Cream Co. v. Fred H. Bean Co., 284 Mass. 239, I 87 N.E. 537 (1933); Bagley v. Reno Oil Co., 201 Pa. 78, 50 Atl. 760, 56 L.R.A. I84 (I902); Johnson v. TribuneHerald Co., I55 Ga. 204, I 6 S.E. 8 10 (1923); Dolbear v. Wilkinson, I 72 Cal. 366, I56 Pac. 488 (1916); Sampson v. Bowdoinham Steam Mill Corp., 36 Me. 78 (1853); 
ment. ${ }^{35}$

The first tendency is the most extreme and thus is the most stringently regarded by the courts. Under this rubric would fall dissolutions, ${ }^{36}$ mergers, ${ }^{37}$ and consolidations. ${ }^{38}$ Likewise, sale of the corporate assets, ${ }^{39}$ as the amount sold increases, become "not part of the business of carrying on the corporation, but rather subversive of it." stringent judicial attitude appears prominently in Starrett $v$. Fifth Ave. ES Twenty-Ninth St. Corp., ${ }^{41}$ where there was a by-law to this effect:

Any meeting of the stockholders may be held without notice, provided all ... are present in person or by proxy, and at such meeting any business may be transacted. (Emphasis added.) ${ }^{42}$

Despite this provision, the court held that another by-law authorizing receipt and action upon reports of officers at the annual meetings did not mean that such a report could, without notice, effectively embody a resolution for the sale of all the corporate assets, although all stockholders were present in person or by proxy.

The second tendency includes the great majority of charter ${ }^{43}$ and by-law $^{44}$ amendments, since it is these documents that ordinarily de-

Lawrence v. I. N. Parlier Estate Co., Is Cal.2d 220, 100 P.2d 765 (1940); Gow v. Consolidated Coppermines Corp., I9 Del. Ch. 172, 165 Atl. 136 (1933); Vogtman v. Merchants' Mortgage \& Credit Co., 20 Del. Ch. 364, I 78 Atl. 99 (1935); Synnott v. Cumberland Bldg. \& Loan Ass'n, 1 I 7 Fed. 379 (6th Cir. 1902).

${ }^{35}$ Mutual Fire Ins. Co. of Montgomery County v. Farquhar, 86 Md. 668, 39 Atl. 527 (1898); Koplar v. Warner Bros. Pictures, 19 F. Supp. 173 (D. Del. 1937); United Gold \& Platinum Mines Co. v. Smith, 44 Misc. 567, 90 N.Y.Supp. 199 (Sup. Ct. I 904); Rogers v. Hill, 6o F.2d I09 (2d Cir. 1932); Gray v. Aspironal Laboratories, 24 F.2d 97 (sth Cir. 1928); Baillie v. Oriental Tel. \& Elec. Co., [1915] 1 Ch. 503 .

${ }^{36}$ McKee v. Home Savings \& Trust Co., 122 Iowa 731, 98 N.W. 609 (1904); St. Mary's Benevolent Ass'n v. Lynch, 164 N.H. 213, 9 Atl. 98 (1887); In re Bridport Old Brewery Co., L.R. I Ch. I9I (1867).

${ }^{37}$ Cooper v. Central Alloy Steel Corp., 43 Ohio App. 455,183 N.E. 439 (1931).

${ }^{38}$ Tuttle v. Michigan Air Line R.R., 35 Mich. 247 (1877).

${ }^{30}$ Smith v. Stone, 21 Wyo. 62, 128 Pac. 612 (Ig12); Starrett Corp. v. Fifth Ave. \& Twenty-Ninth St. Corp., I F. Supp. 868 (S.D.N.Y. 1932); Stockholders of Shelby R.R. v. Louisville, C. \& L. R.R., 12 Bush 62 (Ky. 1876); Beggs v. Myton Canal \& Irrigation Co., 54 Utah 120, 179 Pac. 984 (1919); Germer v. Triple-State Natural Gas \& Oil Co., 60 W.Va. 143, 54 S.E. 509 (1906).

${ }^{10} \mathrm{M}$ 'Clean v. Bradley, 282 Fed. $101 \mathrm{r}$, 1018 (N.D. Ohio 1922).

11 F. Supp. 868 (S.D.N.Y. 1932).

${ }^{12} I d$. at 872 . Observe that this by-law codifies the waiver-by-proxy theory relied upon by some courts to sustain business conducted at stockholders' meetings against the claim of inadequate notice. See notes 61 and 66 infra.

${ }^{13}$ Johnson v. Tribune-Herald Co., 155 Ga., 204, 116 S.E. 810 (1923).

"Klein v. Scranton Life Ins. Co., 139 Pa. Super. 369, 1 I A.2d 770 (1940); Jones 
lineate the system of corporate functioning. Amendments which may possibly shift the control of the corporation would be extraordinary business, whether the shift is effectuated by altering the composition of the board of directors ${ }^{45}$ changing their tenure, ${ }^{46}$ or redistributing voting rights among stockholders. ${ }^{47}$ Similarly, changes in the manner in which the profits of the enterprise are channeled to the owners would be subsumed here. 48

As for the third tendency-to advance the interests of management - the proper approach would seem to be to determine not solely the amount of fraud or over-reaching possibly involved, but also the point to which the interests of officers and directors are furthered, however legitimately. ${ }^{49}$ Since this is usually the least extreme of the tendencies classified, the cases falling herein tend more to comprise that troublesome twilight zone between the ordinary and the extraordinary in corporate business. A comparison of three cases involving compensation of directors will demonstrate the consequent diversity of treatment that may be expected in this area.

In United Gold E Platinum Mines v. Smith, ${ }^{50}$ stock was issued to a director for services performed in effecting the consolidation of his corporation with another. The court, although admitting that there was no evidence of unfairness, allowed stockholders of the consolidated corporation to cancel the stock bonus on the ground that its issuance had not been sufficiently embodied in the notice of meeting. ${ }^{51}$ Although this

v. Concord \& M. R.R., 67 N.H. II9, 38 Atl. 120 (I892); Bagley v. Reno Oil Co., 20I Pa. 78, 50 Atl. 760, 56 L.R.A. 184 (1902); Bushway Ice Cream Co. v. Fred H. Bean Co., 284 Mass. 239, 187 N.E. 537 (1933); Gow v. Consolidated Coppermines Corp., I9 Del. Ch. 172, I65 Atl. 136 (1933).

${ }^{25}$ Tuttle v. Michigan Air Line R.R., 35 Mich. 247 (I877).

${ }^{4}$ Klein v. Scranton Life Ins. Co., 139 Pa. Super. 369, I I A.2d 770 (1940).

${ }^{47}$ Vogtman v. Merchants' Mortgage \& Credit Co., 20 Del. Ch. 364, I78 Atl. 99 (1935); Synnott v. Cumberland Bldg. \& Loan Ass'n, 117 Fed. 379 (6th Cir. 1902).

${ }^{48}$ Jones v. Concord \& M. R.R., 67 N.H. II9, 38 Atl. 120 (I\$9z); Danzig v. Lacks, 235 App.Div. 189, 256 N.Y.Supp. 769 (1932); Synnott v. Cumberland Bldg. \& Loan Ass'n, 117 Fed. 379 (6th Cir. 1902).

${ }^{\circ}$ Mutual Fire Ins. Co. of Montgomery County v. Farquhar, 86 Md. 668, 39 Atl. 527 (1898); Baillie v. Oriental Tel. \& Elec. Co., [1915] I Ch. 503; United Gold \& Platinum Mines Co. v. Smith, 44 Misc. 567, go N.Y.Supp. 199 (Sup. Ct. I904). Cf. Koplar v. Warner Bros. Pictures, 19 F. Supp. 173 (D. Del. 1937); Rogers v. Hill, 60 F.2d I09 (2d Cir. I932); Gray v. Aspironal Laboratories, 24 F.2d 97 (5th Cir. $192 \mathrm{~S}$ ).

${ }^{80} 44$ Misc. 567, 90 N.Y.Supp. I 99 (Sup. Ct. 1904).

${ }^{51}$ The notice stated that the meeting was "for the purpose of considering a plan of amalgamating the interests and properties of this company with that of [another], and for such other business in relation thereto, as well as the general business of the company, as may be presented to the meeting." 90 N.Y.Supp, at 202 (Sup. Ct. I904). 
rule seems sound, ${ }^{52}$ it may have been applied too rigorously in Baillie v. Oriental Telephone Es Electric Co. ${ }^{53}$ There, the directors, having paid themselves large salaries for several years, called a stockholders' meeting for the stated purpose of having their action ratified. The notice in question omitted only to indicate the amount paid, ${ }^{54}$ and the court found that there was no overreaching and no suggestion that the action would not be affirmed by reasonable stockholders. Nevertheless, the omission of the one detail of amount was held to invalidate the notice..$^{55}$ By way of contrast, in Gray v. Aspironal Laboratories, ${ }^{56}$ the complaining stockholder who sought to recover for the corporation the value of the stock issued to its president under questionable circumstances was denied this remedy by an incongruous application of straight agency principles. ${ }^{57}$ Although she had no personal knowledge of the transaction, the stockholder was held to be estopped by the imputation of her proxy-holder's knowledge to her. ${ }^{58}$

\section{InTERVENTION of ThIRd-PARTY INTERESTS-EFFECT on Decisions}

When the above analysis is applied only to cases resolving conflicts among stockholders, there seems to emerge, despite numerous variables and occasional aberrational decisions, a rather symmetrical framework within which policy considerations can be weighed and equitable results technically rationalized with reasonable consistency. Thus, the interests of the corporation and stockholders as a group can be balanced against those of a dissentient minority claiming deprivation of due notice, and the conclusions can be stated in terms of the extent to which the matter diverges from normal corporate functions. When the interests of third parties are introduced, however, complications result from the lack of judicial articulation of the basic thesis here advancedthat is, that requirement of notice is grounded in certain rights of individual stockholders, which are subject to the limitations imposed by rights of other stockholders and of third parties. Consistency then be-

52 The rale that the personal interests of directors cannot be advanced at a stockholders' meeting unless adequate notice is given is a direct sanction on directors, compelling their proper conduct relating to the informational needs of the stockholders. Consequently, the very stringent application of notice requirement rules in such a situntion can be justified as a prophylactic measure. See note 93 infra.

${ }^{5}\left[\mathrm{Ig}_{9} \mathrm{I}_{5}\right]$ I Ch. 503 .

54 See note 29 supra.

${ }^{5 t}$ It appears that, in general, the English courts would demand a more complete specification of details in a notice of meeting. 8 r SoL. J. 875 (1937).

${ }_{20} 24$ F.2d 97 ( 5 th Cir. 1928).

57 Note I 9 supra.

ss "She is bound by the act of her proxy, even though she had no personal knowledge of it, becanse he was her agent and she is chargeable with his knowledge." 24 F.2d at $97-98$ ( 5 th Cir. 1928 ). 
gins to give way to the demands of ultimate justice seeking a set of juridically recognized formulae.

The singularly apposite case of Mackenzie v. Taggart ${ }^{59}$ illustrates this point. The notice of the annual meeting, at which a mortgage of corporate property previously executed by the board of directors was ratified by boiler-plate resolution, was patently insufficient to authorize such business. ${ }^{60}$ The trial court, however, nonsuited the complainant stockholder on the ground that the "stockholders who were there and participated in person or by proxy should have known about it more than anyone else. If they had no right to take this action because the meeting was not properly called, they should not have taken it."101 (Emphasis added.) The Colorado Supreme Court, in a split decision, ${ }^{62}$ adopted this reasoning, but with the intimation that the protection of "subsequently accruing rights of third parties"63 was the guiding policy consideration. Such a rationale obviously nullifies the requirement of notice; any matter on which a proxy-holder votes is a "proper" matter before the meeting.

\section{Spurious Complaints by Stockholders}

The internal consistency of this framework of guiding principles undergoes further erosion as stockholders seek to invoke notice requirement rules for the advancement of ulterior ends rather than for the protection of their voting rights. The most representative of these cases fall into two groups. In the first, changed economic conditions prompt a stockholder to seize upon the claim of insufficient notice in order to extricate himself from an unfavorable financial position. ${ }^{64}$ Thus, in Columbia National Bank v. Matheres, ${ }^{65}$ upon insolvency of the corporation, a stockholder sought rescission and recovery of subscription price even after having received dividends on stock issued at an inadequately noticed meeting. In denying relief, the court said: "Any irregularity ... which could be waived by [plaintiff] if personally

${ }^{80}$ rox Colo. 357,73 P.2d 978 (1937).

${ }^{00}$ The notice stated that the meeting was "for the purpose of electing directors of the company and for the transaction and ratification of any and all other business that may come before said meeting." Id. at 360, 73 P.2d at 979 (1937).

${ }^{01} I d$. at 365,73 P.2d at 98 I (1937).

02 The dissent objected that "the plaintiff stockholder had nothing like that detailed and complete knowledge of pertinent facts which is a prerequisite to binding a person by ratification." Id. at 367,73 P.2d at 982 (1937).

${ }^{03}$ Id. at 366,73 P.2d at 982 ( 1937 ).

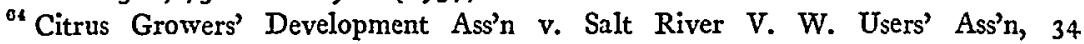
Ariz. 105, 268 Pac. 773 (1928); Foote v. Greilick, I66 Mich. 636, 132 N.W. 473 (1911); Columbia Nat'l Bank v. Mathews, 85 Fed. 934 (9th Cir. I898); M'Clean v. Bradley, 282 Fed. rox (N.D. Ohio 1922).

${ }^{\text {or }} 85$ Fed. 934 (9th Cir. 1898 ). 
present, could be waived by his proxy, and such waiver is binding on him."

The second group includes two cases ${ }^{67}$ in both of which a faction of an erstwhile evenly balanced close corporation gained complete control, and the other faction resorted to the purely technical claim ${ }^{68}$ of inadequate notice as a counterattack. The trial court in one of these cases $^{69}$ took the position that "no stockholder can urge the invalidity of such meeting for want of notice, unless he has been injured ... by lack of notice."70 On appeal, however, it was held in both cases that lack of adequate notice rendered the business conducted "void,"71 and therefore that complete knowledge of what was happening ${ }^{72}$ or even the presence of the stockholders in person ${ }^{73}$ did not waive the objection. The desire of the courts to restore the status quo in these cases is perceptible, but their reasoning can hardly be applauded if even a minimum of consistency is sought. As the waiver-by-proxy theory of the first group of cases ${ }^{74}$ virtually extinguishes all protection to stockholders contemplated by requirement of notice, so the no-waiver-atall theory of this second group ${ }^{75}$ reaches the opposite extreme in extending to stockholders protection not contemplated by requirement of notice.

\section{Standing of Third Parties to Complain}

If stockholders themselves have only limited justification for complaining of inadequate notice, then surely the promotion of further inconsistencies should be averted by an open recognition that third parties have no standing at all to claim protection under notice requirement rules. ${ }^{76}$ This was the approach adopted in Beecher v. Marquette

${ }^{66} I d$. at 942 .

${ }^{67}$ Dunster v. Bernards Land \& Sand Co., 74 N.J.L. 132, 65 Atl. 123 (1906); People v. Mathiesson, 269 III. 499, I 09 N.E. 1056 (1915).

${ }^{88}$ T.e., in each case the plaintiff stockholder had suffered no injury by reason of lack' of due notice. See note 88 infra.

${ }^{60}$ People v. Mathiesson, 269 Ill. 499, 109 N.E. 1056 (1915).

${ }^{70} \mathrm{Id}$. at 503, 109 N.E. at 1057 (1915).

${ }^{71}$ See note 80 infra.

${ }^{72}$ In Dunster v. Bernards Land \& Sand Co., 74 N.J.L. 132, 65 Atl. 123 (1906), it appeared that the plaintiff stockholder had been seeking to secure control of the corporation for himself and had refused to attend the inadequately noticed meeting in a deliberate attempt to frustrate the election of directors by the faction opposing him.

${ }^{73}$ In People v. Mathiesson, 269 Ill. 499, 109 N.E. 1056 (1915), the meeting was convened without notice, as had been the practice for the past twenty years. The plaintiff stockholders attended but left after an altercation with the opposing faction.

${ }^{74}$ Note 64 supra.

${ }^{75}$ Note 67 supra.

${ }^{76}$ The recognition that this would be the desirable result has prompted an unqualified assertion that the law in this respect is as it should be: "So clearly are the 
E Pacific Rolling Mill Co., ${ }^{77}$ wherein the corporation's property was mortgaged without the notice to stockholders required by statute. ${ }^{78}$ The purchaser of the corporation's equity of redemption in the mortgaged property asserted this lack of due notice as against the mortgagee. After a discussion of the distinction between "void" and "voidable,"79 the court concluded that business conducted at an inadequately noticed meeting was voidable at the election of the stockholders only, since it was for their protection that the notice was required. ${ }^{80}$

Unfortunately, other courts have dealt with these cases by an indiscriminate application of the rules sought to be invoked. ${ }^{81}$ The usual result has been a quite proper denial of any protection to the complaining third party; ${ }^{82}$ but language in Tilden v. Quaker Oats Co., ${ }^{83}$ where proxies of stockholders were voted by the directors in favor of the sale of all the corporate assets, offers a disturbing example of the extreme position to which such an application might lead:

Concealment of an intention to transact certain business at a shareholders' meeting is not a violation of any right of a shareholder who gives a proxy broad enough to cover the particular business complained of. ${ }^{84}$

And at the opposite extreme, American Tube Works v. Boston Machine $\mathrm{Co}^{85}$ demonstrates how, even with such outlets as waiver and estoppel available, a court may be compelled to a result equally as detrimental to the interests of stockholders by a literal application of the skeleton principle that notice must always be given if the business is extraordinary. The plaintiff, a creditor who had accepted "special stock" in payment for his debt and had received dividends thereon for

formal requirements as to shareholders' meetings for the benefit of the shareholders themselves, that it is held that the validity of corporate action cannot be attacked collaterally because of formal irregularities. . .." Stevens, Corporations $\S$ irg, at 539 (2d ed. 1949).

${ }_{77} 45$ Mich. 103,7 N.W. 695 (1881).

${ }^{78} \mathrm{Id}$. at 105-06, 7 N.W. at 695 (188r).

${ }^{70}$ The court concluded that "the word void in a statute might be construed as voidable where the provision is introduced for the benefit of [certain] parties only. . .." $I d$. at 108,7 N.W. at 696 (188x).

${ }^{B 0}$ "If the manifest intent is to give protection to determinate individuals [i.e., stockholders], the purpose is sufficiently accomplished if they are given the liberty of avoiding [the business]." Id. at 108, 7 N.W. at 697 (188x).

${ }^{81}$ See e.g., American Tube Works v. Boston Mach. Co., 139 Mass. 5, 29 N.E. 63 (1885); Evans v. Boston Heating Co., 157 Mass. 37, 3I N.E. 698 (I892); Richardson v. Vermont \& Massachusetts R.R., 44 Vt. $61_{3}$ (1872).

${ }^{82}$ E.g., Evans v. Boston Heating Co., I57 Mass. 37, 31 N.E. 698 (1892).

${ }^{83}$ I F.2d I60 (7th Cir. 1924).

${ }^{81} \mathrm{Id}$. at 166 .

${ }^{85}{ }_{139}$ Mass. 5,29 N.E. 63 (1885). 
two and a half years, was allowed to rescind as against the insolvent corporation on the ground that the notice of the meeting at which the stock was issued was inadequate.

\section{Conclusion}

The readiest conclusion adduced by the foregoing discussion is that the common law rules of adequate notice have been so overburdened by the liberty with which they have been applied that the protection now afforded stockholders is frequently either quite illusory ${ }^{80}$ or too rigidly absolute. ${ }^{87}$ Hence, it appears that the course of judicial and legislative reform in this field should tend toward a more selective application of the adequacy-of-notice test. No stockholder should be heard to complain of inadequate notice unless this invasion of his rights to be informed directly bears upon the gravamen of the litigation. ${ }^{88}$ Any receipt of benefits ${ }^{89}$ or other action manifesting acquiescence on his part ${ }^{90}$ should foreclose a stockholder's claim immediately; and nothing but the most diligent pursuit of his rights, ${ }^{01}$ especially when the interests of third parties have become involved, ${ }^{92}$ should redound to his benefit.

It may be objected that such stringent limitations on the right of a stockholder to question the validity of inadequately noticed business will abate the compelling force of notice requirement rules as an inducement for proper disclosure. But it has become apparent that the rules in question are relatively inefficient restraints on corporate mismanagement. $^{.33}$ In order to provide a minimum of compulsion on directorate practices, the force of the law must be such that dispropor-

\footnotetext{
${ }^{80}$ See, e.g., note 56 supra.

${ }^{87}$ See, e.g., note 67 supra.

${ }^{88}$ See note 68 supra. From such a position it would follow, a fortiori, that no creditor could complain of lack of due notice. Note 77 stupra.

${ }^{80}$ Note 22 supra.

oo "The [stockholders] may possibly have had a right to take advantage of the exact words of the statute [requiring notice], repudiate their action, and treat the mortgage as of no force or effect, but they had an equal right to treat it as effective and valid." Beecher v. Marquette \& Pacific Rolling Mill Co., 45 Mich. 103, 109, 7 N.W. 695,697 (188r).

${ }^{01}$ Note 23 supra.

${ }^{82}$ Note 63 supra. If a case arose in which even the most active diligence on the part of the stockholder could not forestall the intervention of the interests of third parties, the ideal solution might be to invalidate the inadequately noticed business and then to allow the injured third party to recoup his losses from the directors. Such a solution would serve the very useful purpose of encouraging the directors to makc notices of meetings adequately informative. See note 52 supra, and note 93 infra.

${ }^{83}$ If the rules requiring adequate notice are violated, the only result will be nullification of the inadequately noticed transaction. Consequently, the rules put little pressure on directors unless they have a personal or financial interest in seeing that the particular transaction is upheld. See note 52 supra.
} 
tionate hardships will result: The solution might well be found in the formulation of a statutory scheme of direct sanctions on directors in order to compel proper disclosure of business to be brought before stockholders' meetings. But this would undoubtedly be difficult of attainment. ${ }^{94}$ Perhaps, therefore, the infusion of more democratic principles into corporate government can be achieved most effectively through the agency of a responsible legal profession in its advisory capacity. ${ }^{95}$

Russeli M. Robinson

\footnotetext{
"Such an extreme measure as the imposition of criminal liability for failure to give notice of meetings in accord with specific statutory requirements would probably not be politically feasible. As for rendering directors civilly liable for their remissness, the problem of damages seems to be one of insuperable difficulty.

${ }^{05}$ "The proper adjustment of the control factor in the corporate system could best be attained at this time on a voluntary basis under the active sponsorship of the legal profession." Caplin, Proxies, Annual Meetings and Corporate Democracy: The Lawyer's Role, 37 VA. L. REv, 653, 686 (I95 X).
} 